OPEN ACCESS

Edited by:

Daniel Joseph Pondella, Occidental College, United States

Reviewed by: Jeremy T. Claisse, California State Polytechnic University, Pomona, United States Ann Scarborough Bull, University of California, Santa Barbara, United States

*Correspondence: Sean van Elden sean.vanelden@research.uwa.edu.au; svanelden@gmail.com

Specialty section: This article was submitted to Marine Ecosystem Ecology, a section of the journal Frontiers in Marine Science

Received: 28 February 2019

Accepted: 20 August 2019 Published: 04 September 2019

Citation:

van Elden S, Meeuwig JJ, Hobbs RJ and Hemmi JM (2019) Offshore Oil and Gas Platforms as

Novel Ecosystems: A Global Perspective. Front. Mar. Sci. 6:548. doi: 10.3389/fmars.2019.00548

\section{Offshore Oil and Gas Platforms as Novel Ecosystems: A Global Perspective}

\author{
Sean van Elden*, Jessica J. Meeuwig, Richard J. Hobbs and Jan M. Hemmi \\ School of Biological Sciences, The University of Western Australia, Crawley, WA, Australia
}

Offshore oil and gas platforms are found on continental shelves throughout the world's oceans. Over the course of their decades-long life-spans, these platforms become ecologically important artificial reefs, supporting a variety of marine life. When offshore platforms are no longer active they are decommissioned, which usually requires the removal of the entire platform from the marine environment, destroying the artificial reef that has been created and potentially resulting in the loss of important ecosystem services. While some countries allow for these platforms to be converted into artificial reefs under Rigs-to-Reefs programs, they face significant resistance from various stakeholders. The presence of offshore platforms and the associated marine life alters the ecosystem from that which existed prior to the installation of the platform, and there may be factors which make restoration of the ecosystem unfeasible or even detrimental to the environment. In these cases, a novel ecosystem has emerged with potentially significant ecological value. In restoration ecology, ecosystems altered in this way can be classified and managed using the novel ecosystems concept, which recognizes the value of the new ecosystem functions and services and allows for the ecosystem to be managed in its novel state, instead of being restored. Offshore platforms can be assessed under the novel ecosystems concept using existing decommissioning decision analysis models as a base. With thousands of platforms to be decommissioned around the world in coming decades, the novel ecosystems concept provides a mechanism for recognizing the ecological role played by offshore platforms.

Keywords: novel ecosystems, Rigs-to-Reefs, decommissioning, artificial reefs, environmental impacts, offshore oil and gas

\section{INTRODUCTION}

Since 1947, when Ship Shoal Block 32 in the Gulf of Mexico became the world's first offshore oil drilling platform (Aagard and Besse, 1973), the offshore energy industry expanded rapidly to currently number over 12,000 offshore installations globally (Ars and Rios, 2017). Offshore platforms are situated on the continental shelves of 53 countries, making offshore oil and gas production a major global industry (Parente et al., 2006). Significant advances in engineering over the last 70 years have not only increased the number of rigs, but also the environmental conditions which they can withstand: offshore platforms are now larger and found in deeper waters, further from shore. These technological advances have implications for decommissioning, which occurs when hydrocarbon production ceases or the lease ends and the platform is shut down. The decommissioning process now takes longer, requires more specialized equipment and, by extension, has become more costly (Kaiser and Liu, 2014). 
A 2016 study by the IHS Markit forecast the global decommissioning of over 600 offshore structures between 2017 and 2021, with a further 2,000 projects by 2040, resulting in a total cost between 2010 and 2040 of US $\$ 210$ billion (IHS Markit, 2016). In countries where total removal is the legal requirement, decommissioning involves the plugging of wells, cleaning, capping and possibly removal of pipelines, removal of production equipment and removal of the structure (Hakam and Thornton, 2000). In United Kingdom waters alone, decommissioning expenditure is forecast to amount to $£ 17$ billion between 2017 and 2025 (Oil and Gas UK, 2017). Even a nation with comparatively low oil and gas production, such as Australia ( $0.9 \%$ of global production), has a future decommissioning liability of US $\$ 21$ billion over the next 50 years (NERA, 2016). The process of decommissioning is far from straightforward in many cases, and is often complicated by the process of transferability, whereby an existing platform is sold to a company which can continue production at lower profit margins (Parente et al., 2006).

From a biological viewpoint, increasing evidence suggests that offshore oil and gas platforms provide significant ecosystem services while active. The installation of these platforms creates hard substrate in open waters which is colonized by a variety of sessile organisms and results in the formation of artificial reefs (Shinn, 1974; Scarborough-Bull, 1989). Because they may exclude commercial fishing, particularly trawling, and in some cases recreational fishing, these platforms can also act as important refuges for a variety of taxa (Frumkes, 2002; Claisse et al., 2014). The potential ecological value of offshore platforms raises the question of whether there may be alternatives to the standard decommissioning process that might have important positive ecological outcomes, and ecological factors are more recently being included in decommissioning assessments (Fowler et al., 2014; Henrion et al., 2015; Sommer et al., 2019). The successes of various Rigs-to-Reefs projects, particularly in the Gulf of Mexico, have demonstrated that these structures can be effectively repurposed as artificial reefs (Frumkes, 2002; Kaiser and Pulsipher, 2005; Sammarco et al., 2014). However, to date only a few countries around the world have successfully implemented Rigs-to-Reefs programs (summarized in Bull and Love, 2019).

Evaluating offshore platforms as novel ecosystems would provide a mechanism for considering the ecological importance of these platforms in the decommissioning process. Novel ecosystems is a relatively recent ecological concept, brought into focus by Hobbs et al. (2006), where human activity has altered ecosystems to a point where restoration may not be feasible. In a world that is increasingly being altered by human activity, the concept of novel ecosystems recognizes that in some cases, ecosystems changed from their historical state by human intervention may not feasibly be able to be restored (Hobbs et al., 2006). With many case studies throughout a variety of ecosystems around the world (Hobbs et al., 2013b), novel ecosystems provide an approach for recognizing value in altered ecosystems, rather than implementing restoration for restoration's sake. In the cases of both active and decommissioned platforms, it is possible that the concept of novel ecosystems can be applied as a way to describe the ecosystems created by the presence of the platforms. The aim of this review is to evaluate the ecological role of offshore oil and gas platforms, and to assess these platforms against the criteria of the novel ecosystems concept.

\section{DECOMMISSIONING}

Decommissioning, the end of life stage for offshore infrastructure, is a process which is regulated internationally, regionally and nationally. The 1996 Protocol to the London Dumping Convention (London Protocol) aimed to protect the marine environment from all sources of pollution, and regulates against the dumping of "... platforms or other man-made structures at sea; and any abandonment or toppling at site of platforms or other man-made structures at sea, for the sole purpose of deliberate disposal." (Elizabeth, 1996). However, the London Protocol does not expressly prohibit decommissioning of structures in situ (Techera and Chandler, 2015), stating that dumping does not include "placement of matter for a purpose other than disposal thereof, provided that such placement is not contrary to the aims of this Protocol (Elizabeth, 1996)." There are four alternatives to complete removal: (1) leave wholly in place with appropriate navigational aids; (2) partial removal, usually of the superstructure); (3) tow-and-place by moving the structure to a new location; and (4) toppling by laying the structure on its side (Schroeder and Love, 2004; Macreadie et al., 2011; Fowler et al., 2014).

Decommissioning regulations and options in various countries and regions have been reported on and assessed extensively in the literature. While decommissioning in the North Sea and the United States (US) has been well studied (e.g., Reggio, 1987; Löfstedt and Renn, 1997; Dauterive, 2000; Cripps and Aabel, 2002; Schroeder and Love, 2004; Kaiser and Pulsipher, 2005; Jørgensen, 2012; Claisse et al., 2015), there has been more recent focus on decommissioning policy in relatively "new" oil and gas producing regions, such as south-east Asia (Zawawi et al., 2012; Al-Ghuribi et al., 2016; Fam et al., 2018; Laister and Jagerroos, 2018), Australia (Fowler et al., 2015; Techera and Chandler, 2015; Chandler et al., 2017), and Brazil (Barros et al., 2017; Mimmi et al., 2017). Two recent reviews (Bull and Love, 2019; Sommer et al., 2019) provide comprehensive assessments of the literature on the decommissioning process, options, and regulations around the world. These two reviews complement each other by focusing on somewhat different aspects of decommissioning. Sommer et al. (2019) focuses on the ecosystem functions and services provided by platforms, and suggests a more ecosystemsbased approach to decommissioning. Bull and Love (2019) provides the most in-depth review to date of the literature on offshore oil and gas platforms, including platform installation, decommissioning, relevant legislation, and platform ecology. While this review is mainly focused on the United States, it does briefly review Rigs-to-Reefs programs in other regions around the world. 


\section{RIGS-TO-REEFS}

Rigs-to-Reefs is a potential decommissioning outcome for offshore oil and gas structures whereby obsolete infrastructure is re-purposed as artificial reefs instead of being brought back to shore for disposal (Kaiser and Pulsipher, 2005). The first examples of Rigs-to-Reefs occurred in the 1980s, when platforms were removed from production in Louisiana and transported to Florida where they were repurposed as artificial reefs (Kaiser, 2006; Jørgensen, 2009).

By April 2018, approximately 532 offshore platforms have been re-purposed as artificial reefs in the Gulf of Mexico, mostly in Louisiana and Texas (Ajemian et al., 2015; Bureau of Safety and Environmental Enforcement, 2018). This represents just over $11 \%$ of the total number of platforms decommissioned in the Gulf of Mexico (Bull and Love, 2019).

Offshore oil and gas platforms are spatially complex structures and their value as artificial reefs has been discussed in numerous studies (Shinn, 1974; Dugas et al., 1979; Bohnsack and Sutherland, 1985; Guerin et al., 2007). Offshore platforms have not only been shown to have a higher fish biomass than sandy bottom areas but even natural reefs (Claisse et al., 2014). This results in offshore platforms having an "enhanced fishing zone" of 200-300 $\mathrm{m}$ for pelagic species and 1-100 $\mathrm{m}$ for demersal species (Bohnsack and Sutherland, 1985). Fishing and diving around offshore rigs, in countries where it is allowed, is a major component of the local tourism industries (Stanley and Wilson, 1989). In Louisiana, recreational fishing is centered around offshore platforms - over $70 \%$ of recreational fishing trips into the EEZ are in direct association with offshore platforms, where pelagic fish densities are 20-50 times higher than surrounding areas (Dugas et al., 1979; Reggio, 1987; Dauterive, 2000). As such, sport fishers and recreational divers generally support Rigs-toReefs programs (Frumkes, 2002).

Both active and decommissioned offshore platforms can have a negative impact on commercial trawl fishing, and the prevention of trawling is a common criticism of Rigs-to-Reefs programs (Macdonald, 1994; Hamzah, 2003). The issue of allowing fishing around platforms is one that is still uncertain and needs to be handled carefully. In some cases where platforms have become key habitat for threatened or economically important species, it may be prudent to continue to exclude all fishing from these areas if they are converted into artificial reefs, as they can then be used to bolster populations at surrounding natural reefs where fishing occurs in the same way that marine protected areas (MPAs) do (Mcclanahan and Mangi, 2000).

In sandy, flat-bottom areas with generally limited physical structure, such as the north-west shelf of Australia, the Adriatic Sea and parts of the North Sea, offshore platforms present some of the only obstacles to trawl nets (Rijnsdorp et al., 1998; Wassenberg et al., 2002; Fabi et al., 2004). While the prevention of trawling is detrimental to commercial fisheries, it is ecologically beneficial in offering protection to benthic habitats; in a study to determine the effect of trawling on sponge communities of the north-west shelf of Australia, sponges were caught in $85 \%$ of trawls, with a mean catch of $87.2 \mathrm{~kg}$ per half-hour (Wassenberg et al., 2002).
Evidence on the success of Rigs-to-Reefs programs and the suitability of oil platforms as artificial reef habitat suggests that these structures can provide significantly more ecological value than other cases of "dumping" (Ajemian et al., 2015). However, it is important to note that just because Rigs-to-Reefs has been successful in a certain area (e.g., the Gulf of Mexico), it does not mean it would automatically be an ecologically beneficial exercise in the North Sea, California or Australia. Every ecosystem is different and needs to be evaluated as such; creating a reef, simply because there is a platform that needs to be decommissioned, is indeed little more than waste disposal (Macdonald, 1994; Salcido, 2005).

A major obstacle in the path of Rigs-to-Reefs legislation is the relative lack of ecological research on offshore structures. For example, despite the presence of over 40 offshore oil and gas installations on the continental shelf of north-west Australia, there has been a limited number of published studies on the ecology of the structures in this region (e.g., Fowler and Booth, 2012; Pradella et al., 2014; McLean et al., 2017, 2018; Bond et al., 2018). Macreadie et al. (2012) concluded that environmental research must be part of the development of Rigs-to-Reefs policy, pointing to the case of California, where a Rigs-to-Reefs bill was vetoed in 2001 based on a lack of evidence that reefed platforms produce net environmental benefits. Macreadie et al. (2012) argue that the subsequent successful passing of a Rigs-to-Reefs bill in 2010 was due in large part to the years of subsequent research by Dr. Milton Love and colleagues (Schroeder and Love, 2002, 2004; Love et al., 2006).

\section{ECOLOGY OF OFFSHORE PLATFORMS}

Offshore oil and gas platforms can play important ecological roles for various taxa (Friedlander et al., 2014). They provide substrate for sessile organisms such as sponges and corals and act as a refuge for fish and megafauna such as seals and whales (Forteath et al., 1982; Todd et al., 2016). When a platform is installed, the establishment of a faunal community occurs quickly, with fish appearing within hours (Bohnsack, 1989), and ecological succession results in a complex reef-type habitat within 5-6 years (Driessen, 1986). Offshore platforms can be an important source of habitat not only for fish, but also for sessile invertebrates where hard substrate is limited. Where offshore platforms are isolated from natural reefs, the free-swimming larval stages of invertebrates that settle on offshore platforms would otherwise not likely survive due to a lack of "hospitable" substrate (Driessen, 1986; Thomson et al., 2003; Macreadie et al., 2011). However, the addition of hard substrate means that offshore platforms can also provide habitat for invasive species (Page et al., 2006; Pajuelo et al., 2016).

There is considerable debate as to whether fish associated with artificial structures are actually being produced there for a net gain, or are simply being attracted from nearby natural reefs. Attraction is thought to be detrimental to fish populations, especially those which are targeted by fisheries, as previously sparsely distributed populations become concentrated, making them vulnerable to exploitation (Bohnsack, 1989). However, in 
the case of offshore platforms, attraction could be beneficial to pelagic species in some regions, where the platforms can act as a temporary refuge from fishing pressure. Macreadie et al. (2011) discuss the importance of habitat limitation as a factor in the attraction vs. production debate; specifically that a habitatlimited fish population would see an increase in regional biomass due to the addition of suitable habitat via artificial structures. Fowler and Booth (2012) found that offshore platforms in northwest Australia could sustain complete size- and age-structured populations of the Serranidae Pseudanthias rubrizonatus, with a presumed age range in sampled individuals of 22 days to 5 years. However, production of fish varied among individual platforms. The relative scales of "attraction vs. production" therefore may vary between offshore oil and gas platforms, as biotic and abiotic conditions vary from platform to platform. The presence of larval fish may not be enough to assume production, based on the proximity of other reefs (Bohnsack, 1989; Macreadie et al., 2011). In addition, production is more important in the case of demersal species, which are more dependent on benthic habitat than highly mobile pelagic species (Bohnsack, 1989).

The ecosystem created by offshore platforms means, like natural reefs, they provide economic benefits. In regions where recreational fishing is permitted, these platforms have been highly popular locations for decades (Dugas et al., 1979). "Fishing the rigs" is a major portion of the recreational fishing activity in the Gulf of Mexico, particularly Louisiana, where species caught at the platforms include sharks, billfish, and barracuda (Driessen, 1986). While recreational fishing occurs around offshore platforms, a number of commercial gear types such as trawl and longline are generally excluded from the waters around these structures due to the risk of damage to both fishing gear and subsea infrastructure such as pipelines (de Groot, 1982; Demestre et al., 2008).

In some regions, the exclusion of all vessels, including recreational and commercial fishers, can be legally mandated, and these "exclusion zones" vary in size between countries. In the North Sea, the exclusion from fishing around offshore oil platforms that have been in place for decades, has resulted in a network of de facto MPAs (de Groot, 1982; Fujii and Jamieson, 2016). In Australia, the "petroleum safety zones" surrounding offshore platforms extend up to $500 \mathrm{~m}$ from the outer edge of any well or structure (Commonwealth of Australia, 2010), while the exclusion zone around a drilling platform in the Jubilee Field in Ghana is five nautical miles (Chalfin, 2018). In 2003, Mexico created an "area of exclusion" of 5,794 $\mathrm{km}^{2}$ around oil platforms in the Campeche region of the Gulf of Mexico (Quist and Nygren, 2015).

Various studies have described oil platforms around the world as de facto MPAs. Because of the exclusion of trawl fishing at all platforms in Gabon, and the exclusion of all types of recreational fishing at some platforms due to security restrictions, Friedlander et al. (2014) concluded that these platforms are functioning as de facto MPAs. In California, offshore oil platforms provide a significant refuge for commercially important rockfish species (Frumkes, 2002; Claisse et al., 2014; Fowler et al., 2015). Marine vessels are discouraged from entering the $150 \mathrm{~m}$ buffer zone surrounding platforms, meaning that fishing activity is limited, and Schroeder and Love (2002) found that rockfish surrounding an oil platform were larger and greater in density compared with the populations at recreationally and commercially fished sites. In addition, eight offshore oil and gas platforms off southern California supported 430,000 juveniles of the highly overfished and IUCN Critically Endangered Bocaccio rockfish Sebastes paucispinis, accounting for $20 \%$ of the average annual number of surviving juveniles of this species. In these instances, the refuges provide much higher recruitment and survival rates than natural but fished nursery grounds (Love et al., 2006).

\section{NOVEL ECOSYSTEMS}

Human activities are transforming ecosystems on a global scale (Foley et al., 2005; Mccauley et al., 2015; Laurance and Watson, 2016). Many studies and conservation efforts focus on restoring altered ecosystems to their historical states (Sanchez-Cuervo et al., 2012; Graham and Mcclanahan, 2013), but over the last two decades, the term "novel ecosystems" has emerged as a way of defining ecosystems altered by human activity, where restoration is at best unlikely (Hobbs et al., 2013a). There has been criticism that the concept may exclude restoration and may provide companies a license to trash ecosystems (Aronson et al., 2014; Murcia et al., 2014). However, the novel ecosystem concept is not intended to replace ecological restoration, but is meant to provide a management option for ecosystems where restoration is not feasible or may actually result in the loss of ecosystem value (Hobbs et al., 2014). In some cases, the novel ecosystem may provide ecosystem services that are more beneficial than those provided by the historical state. Backstrom et al. (2018) have suggested that the novel ecosystems concept is most useful in a decision or management context and in terms of meeting social, ecological and economic objectives.

The term novel ecosystems was first used in 1997 (Chapin and Starfield, 1997) but was introduced into terrestrial conservation and restoration ecology fields in 2006 (Hobbs et al., 2006). The concept has more recently been adopted by some marine ecologists, where studies on marine novel ecosystems have generally focused on coral reefs which have been altered by direct human activity, disease, climate change or introduced species (Graham et al., 2013, 2015; Yakob and Mumby, 2013; Hehre and Meeuwig, 2015). However, the concept has not yet gained significant traction amongst marine ecologists. Schläppy and Hobbs (2019) provide a comprehensive decision-making framework for applying the novel ecosystems concept to altered marine ecosystems. This framework creates a mechanism for the novel ecosystems concept to be more widely applied to marine ecosystems in future. While Schläppy and Hobbs only briefly discuss offshore platforms, Sommer et al. (2019) suggest that the ecosystem-level shifts occurring around offshore platforms are "consistent with the science on... novel ecosystems." However, while drawing parallels between offshore platforms and novel ecosystems, the authors do not explore the concept further, nor do they discuss the application of the concept to some or all offshore platforms. 
The degree to which offshore platforms can usefully be considered a novel ecosystem may assist in assessing decommissioning options. Offshore platforms can be broadly assessed in a novel ecosystems context by evaluating these platforms against the criteria outlined in the most recent novel ecosystems definition from Hobbs et al. (2013b):

Criterion 1: The abiotic, biotic and social components of the system "differ from those that prevailed historically." In the case of offshore oil and gas platforms, the abiotic and biotic states of the target ecosystem have clearly been altered due to anthropogenic forcing, specifically due to the installation of a large artificial structure and the associated disturbance of the ecosystem. Examples of this include the growth of cold-water corals on platforms in the North Sea (Gass and Roberts, 2006) and the aggregation of whale sharks around platforms in Qatar (Robinson et al., 2013) both of which are novel qualities not previously present in the historical state of the ecosystem.

Criterion 2: The ecosystems have a "tendency to self-organize and manifest novel qualities without intensive human management." In the case of offshore oil and gas platforms, the marine life associated with offshore platforms is not managed in any way, apart from limited maintenance cleaning to remove sessile invertebrates. These ecosystems persist over the lifespan of the platform, with reports of thousands of tons of invertebrate growth on the subsea structures of platforms (Foster and Willan, 1979; Culwell, 1997). Novel qualities manifested by platforms include higher productivity of algae and invertebrates (Chou et al., 1992) and higher fish biomass (Love et al., 2006).

Criterion 3: Novel ecosystems are prevented from returning to their historical states by practical limitations, in the form of ecological, environmental and social considerations. In the context of offshore platforms, these considerations can include many of the factors evaluated by stakeholders during the decommissioning process (Table 1). However, some considerations may be context specific rather than absolute, and vary among regions. For example, in California where there are relatively few platforms, their role in providing habitat for economically important species such as rockfish makes individual platforms ecologically important, particularly as some platforms produce more of these species than others (Schroeder and Love, 2002). Conversely, in an area such as the Gulf of Mexico with thousands of platforms, the ecological value of an individual platform within a regional context is not necessarily as high and therefore may not be an important ecological consideration (Schroeder and Love, 2004).

Environmental limitations could prevent the removal of offshore platforms, which means that the ecosystem cannot be returned to its historical state. Complete removal decommissioning is a potentially hazardous process both to the environment and personnel, and particularly in regions with harsh weather conditions, decommissioning could be more of a risk than leaving structures in place (Löfstedt and Renn, 1997; OGP Decommissioning Committee, 2012; Ars and Rios, 2017). Additionally, offshore platforms are known as vectors for invasive species, as they are transported long distances at low speed (Page et al., 2006; Pajuelo et al., 2016). The potential transport and spread of the many sponge, algae, coral, and even fish species associated with platforms, could be a factor preventing platform removal, and therefore restoration to historical state.

Perhaps the most significant consideration in the case of offshore platforms is the social aspect. Social factors could prohibit removal of platforms, due to prohibitive costs or platform design making removal unfeasible (Faber et al., 2001; OGP Decommissioning Committee, 2012). The social benefits derived from a platform, in the form of an artificial reef utilized by recreational divers and fishers, could be lost if the platform is removed. Conversely, social opposition to the presence of offshore platforms, as is the case in California (Pietri et al., 2011), or legislation prescribing complete removal, as is the case in Australia (Techera and Chandler, 2015) could lead to the complete removal of platforms, thereby possibly returning the ecosystem to its historical state.

It is important to avoid a blanket classification of all offshore platforms as novel ecosystems. Offshore platforms always result in the creation of habitat, but this does not by default mean that they result in novel ecosystems. For example, a platform placed near a natural reef may not significantly alter the abiotic or biotic components of the ecosystem, and may rather act simply as an "extension" of the existing reef. However, a platform placed in an area with little natural hard substrate significantly alters the abiotic nature of the ecosystem by increasing the hard substrate available, leading to changes in the community of species within the ecosystem, thereby transforming the ecosystem from its historical state.

The novel ecosystems concept can be applied to offshore platforms, so long as it is applied on a case-by-case basis. This is particularly important if the concept is used as part of the decommissioning process, as there may be incentive for energy companies to suggest platforms are novel ecosystems to avoid the costs associated with complete removal. The concept should therefore be applied conservatively and with robust evidence from ecological studies. Various studies have proposed decision analysis frameworks which assess different decommissioning alternatives based on multiple attributes (e.g., Fowler et al., 2014; Bernstein, 2015; Henrion et al., 2015). Some of these attributes can be placed within the novel ecosystems criteria as demonstrated in Table 1. Therefore, an assessment can be made of whether an offshore platform is a novel ecosystem simply by using existing decommissioning analysis tools. From an ecological perspective, decommissioning of offshore platforms is an ecological restoration issue. Novel ecosystems provides a tool for recognizing and retaining ecological value created through human activity, as an alternative to ecological restoration. In the same way, Rigs-to-Reefs provides the same tool, as an alternative to complete platform removal.

The decision framework for managing altered marine systems proposed by Schläppy and Hobbs (2019) would 
TABLE 1 | Examples from the literature of practical considerations preventing offshore platform sites from being returned to their historical state.

\begin{tabular}{|c|c|c|}
\hline Practical limitations & Example & References \\
\hline \multirow[t]{5}{*}{ Ecological considerations } & Refuge for endangered and/or economically important species & Love et al., 2006 \\
\hline & Proportion of regional hard substrate provided by the platform & Love et al., 2003 \\
\hline & Attraction of fish from natural habitats, making them more vulnerable to fishing & Cowan and Ingram, 1999 \\
\hline & Risk of environmental contamination during removal & OGP Decommissioning Committee, 2012 \\
\hline & Highly productive ecosystem & Claisse et al., 2014 \\
\hline \multirow[t]{4}{*}{ Environmental considerations } & Spread of invasive species during removal/transport & Page et al., 2006 \\
\hline & Environmental damage caused by use of explosives during removal process & Kaiser and Pulsipher, 2003 \\
\hline & Disturbance of shell mounds and remobilization of toxic chemical contaminants & Phillips et al., 2006 \\
\hline & Cost of decommissioning & OGP Decommissioning Committee, 2012 \\
\hline \multirow[t]{5}{*}{ Social considerations } & Platform design making removal unfeasible & Parente et al., 2006 \\
\hline & Public support for Rigs-to-Reefs programs & Kaiser and Pulsipher, 2005 \\
\hline & Legal frameworks prescribing complete removal & Techera and Chandler, 2015 \\
\hline & Public opposition to the presence of platforms & Frumkes, 2002 \\
\hline & Obstruction to commercial fishing & Fabi et al., 2004 \\
\hline
\end{tabular}

be a useful starting point for broadly classifying offshore platforms as novel ecosystems - however, because of the suite of complex, and in some cases contentious, issues surrounding oil and gas platforms, there are more factors that need to be taken into account. In this regard, the decommissioning decision analysis frameworks cited above could be used to assess a platform as a novel ecosystems even if decommissioning isn't yet being considered. For example, using the PLATFORM computer model for decommissioning analysis, Henrion et al. (2015) evaluated the impact of decommissioning options on attributes such as cost, benthic impacts, fish productivity, and water quality, all of which can be considered under novel ecosystems criterion 3 in this review.

\section{CONCLUSION}

Offshore oil and gas platforms play an ecological role for a wide variety of marine life, from corals and sponges (Gass and Roberts, 2006; Friedlander et al., 2014), to fish and sharks (Dugas et al., 1979; Schroeder and Love, 2002; Pradella et al., 2014), to marine megafauna (Robinson et al., 2013; Todd et al., 2016). At the end of their productive life, these platforms are generally removed completely and disposed of onshore, effectively removing the hard substrate and associated marine growth from an ecosystem that has developed over upward of 30-40 years (Driessen, 1986; Ferreira and Suslick, 2001). There is strong opposition to offshore drilling, and the negative perceptions of oil companies and their intentions is a big obstacle in the path of Rigs-to-Reefs programs (Löfstedt and Renn, 1997; Pietri et al., 2011). The costs of decommissioning offshore oil and gas infrastructure over the next 20-30 years run into the tens of billions of US dollars, with thousands of structures set to reach their end-of-life in this period (IHS Markit, 2016; Oil and Gas UK, 2017). In some countries, governments (and therefore taxpayers) cover some of the decommissioning costs; in the North Sea alone, this government expenditure could reach US $\$ 6.3$ billion (Parente et al., 2006). Conversely, the ecosystems created by these offshore platforms have an intrinsic value in terms of fisheries, tourism, and conservation that cannot be ignored. As such, the ecological cost of decommissioning in the form of the destruction of these ecosystems must be an integral part of the decommissioning debate.

Based on the analysis of the novel ecosystems concept, many offshore oil and gas platforms can be defined as novel ecosystems, depending on a variety of factors. These platforms warrant further study, on a case-by-case basis, within the framework of novel ecosystems. This does not mean that restoration of these ecosystems should no longer be considered, as restoration may be feasible in many cases and therefore should be an option when a particular platform is to be decommissioned. However, classifying suitable offshore platforms as novel ecosystems allows for the recognition of the established, yet underappreciated, ecological value that these platforms provide.

The novel ecosystems concept can contribute to the consideration of decommissioning options using existing decommissioning decision analysis tools. Hobbs et al. (2017) proposed implementing a portfolio of approaches whereby management goals are based on the relative values of ecosystems. This approach recognizes the importance of altered ecosystems, while still allowing for conservation of high-value unaltered ecosystems. Applying this approach to decommissioning would involve identifying ecologically important platforms to be left in place for the ecosystem services they provide, while focusing decommissioning resources and effort on less ecologically valuable platforms.

One of the key arguments against novel ecosystems is that they give companies a "license to trash' or 'get out of jail' card" (Murcia et al., 2014). This echoes the core opposition to Rigs-to-Reefs; namely that it is simply an excuse for dumping at sea (Macdonald, 1994). This argument, in both cases, ignores the potential ecological value of anthropogenically altered ecosystems. While it is undeniable that companies benefit financially from 
Rigs-to-Reefs programs, this does not automatically mean that these programs are environmentally detrimental. It should be possible to ensure that any Rigs-to-Reefs policy is robust and comprehensive enough to ensure that any reefing of offshore platforms will benefit the environment.

\section{AUTHOR CONTRIBUTIONS}

SE and JM conceived the study. SE wrote the first draft of the manuscript. All authors contributed to the manuscript revision, read, and approved the submitted version.

\section{REFERENCES}

Aagard, P. M., and Besse, C. P. (1973). A review of the offshore environment - 25 years of progress. J. Pet. Technol. 25, 1355-1360. doi: 10.2118/4699-pa

Ajemian, M. J., Wetz, J. J., Shipley-Lozano, B., Dale Shively, J., and Stunz, G. W. (2015). An analysis of artificial reef fish community structure along the northwestern gulf of Mexico Shelf: potential impacts of "rigs-to-reefs" Programs. PLoS One 10:e0126354. doi: 10.1371/journal.pone.0126354

Al-Ghuribi, T. M. Q., Liew, M. S., Zawawi, N. A., and Ayoub, M. A. (2016). "Decommissioning decision criteria for offshore installations and well abandonment," in Engineering Challenges for Sustainable Future: Proceedings of the 3rd International Conference on Civil, Offshore and Environmental Engineering (ICCOEE 2016, Malaysia, 15-17 Aug 2016), (Boca Raton, FL: CRC Press), 81-85. doi: 10.9774/gleaf.9781315375052_16

Aronson, J., Murcia, C., Kattan, G. H., Moreno-Mateos, D., Dixon, K., and Simberloff, D. (2014). The road to confusion is paved with novel ecosystem labels: a reply to Hobbs et al. Trends Ecol. Evol. 29, 646-647. doi: 10.1016/j.tree. 2014.09.011

Ars, F., and Rios, R. (2017). Decommissioning: A Call for a New Approach. Houston, TX: Offshore Technology Conference, doi: 10.4043/27717-MS

Backstrom, A. C., Garrard, G. E., Hobbs, R. J., and Bekessy, S. A. (2018). Grappling with the social dimensions of novel ecosystems. Front. Ecol. Environ. 16, 109-117. doi: 10.1002/fee.1769

Barros, J. C., Fernandes, G. C., Silva, M. M., Da Silva, R. P., and Santos, B. (2017). "Fixed platforms at ageing oil fields - feasibility study for reuse to wind farms," in Proceedings of the Offshore Technology Conference, Houston, TX.

Bernstein, B. B. (2015). Evaluating alternatives for decommissioning California's offshore oil and gas platforms. Integr. Environ. Assess. Manag. 11, 537-541. doi: 10.1002/ieam.1657

Bohnsack, J. A. (1989). Are high densities of fishes at artificial reefs the result of habitat limiatation or behavioural preference? Bull. Mar. Sci. 44, 631-645.

Bohnsack, J. A., and Sutherland, L. (1985). Artificial reef research_a review with recommendations for future priorities. Bull. Mar. Sci. 37, 11-39.

Bond, T., Partridge, J. C., Taylor, M. D., Langlois, T. J., Malseed, B. E., Smith, L. D., et al. (2018). Fish associated with a subsea pipeline and adjacent seafloor of the North West Shelf of Western Australia. Mar. Environ. Res. 141, 53-65. doi: 10.1016/j.marenvres.2018.08.003

Bull, A. S., and Love, M. S. (2019). Worldwide oil and gas platform decommissioning: a review of practices and reefing options. Ocean Coast. Manag. 168, 274-306. doi: 10.1016/j.ocecoaman.2018.10.024

Bureau of Safety and Environmental Enforcement, (2018). Rigs to Reefs. Available at: https://www.bsee.gov/what-we-do/environmental-focuses/rigsto-reefs (accessed June 20, 2018).

Chalfin, B. (2018). Governing Offshore Oil: mapping maritime political space in ghana and the western gulf of guinea. South Atl. Q. 114, 101-118. doi: 10.1215/ 00382876-2831312

Chandler, J., White, D., Techera, E. J., Gourvenec, S., and Draper, S. (2017). Engineering and legal considerations for decommissioning of o ff shore oil and gas infrastructure in Australia. Ocean Eng. 131, 338-347. doi: 10.1016/j. oceaneng.2016.12.030

Chapin, F. S., and Starfield, A. M. (1997). Time lags and novel ecosystems in response to transient climatic change in arctic Alaska. Clim. Chang 35, 449-461.

\section{FUNDING}

This manuscript forms part of the Ph.D. thesis of SE. The Ph.D. is funded by the VOGA Ph.D. Scholarship in Rigs-to-Reefs Ecology, awarded by the University of Western Australia with funds donated by the Vermilion Oil and Gas Australia (Pty) Ltd.

\section{ACKNOWLEDGMENTS}

Our thanks to the Vermilion Oil and Gas Australia (Pty) Ltd. for their support of this project.

Chou, L. M., Lim, G. S. Y., and Leng, C. B. (1992). "Fish communities in natural reef and artificial habitats in he coastal waters of Brunei Darussalam," in The Coastal Resources of Brunei Darussalam: Status, Utilization and Management, (George Town: WorldFish).

Claisse, J. T., Pondella, D. J., Love, M., Zahn, L. A., Williams, C. M., and Bull, A. S. (2015). Impacts from partial removal of decommissioned oil and gas platforms on fish biomass and production on the remaining platform structure and surrounding Shell mounds. PLoS One 10:e135812. doi: 10.1371/journal. pone. 0135812

Claisse, J. T., Pondella, D. J., Love, M., Zahn, L. A., Williams, C. M., Williams, J. P., et al. (2014). Oil platforms off California are among the most productive marine fish habitats globally. Proc. Natl. Acad. Sci. U.S.A. 111, 15462-15467. doi: 10.1073/pnas.1411477111

Commonwealth of Australia, (2010). Offshore Petroleum and Greenhouse Gas Storage Act 2010. Available at: https://www.legislation.qld.gov.au/LEGISLTN/ CURRENT/G/GreenGasSA09.pdf (accessed March 12, 2018).

Cowan, J. H., and Ingram, W. (1999). The Attraction vs. Production Debate: does it really matter from the management perspective? A response to the commentary by Shipp, R. L., 1999, Gulf of Mexico Science XVII, 51-55. Gulf Mex. Sci. 17, 137-138. doi: 10.18785/goms.1702.11

Cripps, S. J., and Aabel, J. P. (2002). Environmental and socio-economic impact assessment of Ekoreef, a multiple platform rigs-to-reefs development. ICES J. Mar. Sci. 59, S300-S308. doi: 10.1006/jmsc.2002.1293

Culwell, A. (1997). "Removal and disposal of deck and jacket structures," in Decommissioning and Removal of Oil and Gas Facilities Offshore California: Recent Experiences and Future Deepwater Challenges, ed. A. Culwell, (Ventura, CA: American Pacific Marine, Inc.), 48-65.

Dauterive, L. (2000). "Rigs-to-reefs policy, progress, and perspective," in Proceedings of the AAUS 20th Symposium Proceedings 2000. Diving for Science in the Twenty-First Century, St. Petersburg, FL, 64-66. doi: 10.2118/ 52709-MS

de Groot, S. J. (1982). The impact of laying and maintenance of offshore pipelines on the marine environment and the North Sea fisheries. Ocean Manag. 8, 1-27. doi: 10.1016/0302-184X(82)90011-90017

Demestre, M., de Juan, S., Sartor, P., and Ligas, A. (2008). Seasonal closures as a measure of trawling effort control in two Mediterranean trawling grounds: effects on epibenthic communities. Mar. Pollut. Bull. 56, 1765-1773. doi: 10. 1016/j.marpolbul.2008.06.004

Driessen, P. K. (1986). “Offshore oil platforms an invaluable ecological resource," in Proceedings of the Oceans 1986 Conference Record, (New York, NY: IEEE Publishing Service), 516-521.

Dugas, R., Guillory, V., and Fischer, M. (1979). Oil Rigs and Offshore Sport Fishing in Louisiana. Fisheries 4, 2-10. doi: 10.1577/1548-8446-21-26

Elizabeth, A. K. (1996). Protocol to the London dumping convention and the Brent Spar. Int. Comp. Law Q. 46, 957-964. doi: 10.1017/s00205893000 61303

Faber, M. H., Kroon, I. B., Kragh, E., Bayly, D., and Decosemaeker, P. (2001). Risk assessment of decommissioning options using bayesian networks. J. Offshore Mech. Arctic Eng. Conf. 124, 231-238.

Fabi, G., Grati, F., Puletti, M., and Scarcella, G. (2004). Effects on fish community induced by installation of two gas platforms in the Adriatic Sea. Mar. Ecol. Prog. Ser. 273, 187-197. doi: 10.3354/meps273187 
Fam, M. L., Konovessis, D., Ong, L. S., and Tan, H. K. (2018). A review of offshore decommissioning regulations in five countries - strengths and weaknesses. Ocean Eng. 160, 244-263. doi: 10.1016/j.oceaneng.2018.04.001. 2018

Ferreira, D. F., and Suslick, S. B. (2001). Identifying potential impacts of bonding instruments on offshore oil projects. Resour. Policy 27, 43-52. doi: 10.1016/ s0301-4207(01)00007-1

Foley, J. A., DeFries, R., Asner, G. P., Barford, C., Bonan, G., Carpenter, S. R., et al. (2005). Global consequences of Land Use. Science 309, 570-575. doi: $10.1126 /$ science. 1111772

Forteath, G., Picken, G., Ralph, R., and Williams, J. (1982). Marine growth studies on the north sea oil platform montrose alpha. Mar. Ecol. Prog. Ser. 8, 61-68. doi: 10.3354/meps008061

Foster, B. A., and Willan, R. C. (1979). Foreign barnacles transported to New Zealand on an oil platform. New Zeal. J. Mar. Freshw. Res. 13, 143-149. doi: 10.1080/00288330.1979.9515788

Fowler, A. M., and Booth, D. J. (2012). Evidence of sustained populations of a small reef fish on artificial structures. Does depth affect production on artificial reefs? J. Fish Biol. 80, 613-629. doi: 10.1111/j.1095-8649.2011.03201.x

Fowler, A. M., Macreadie, P., and Booth, D. (2015). The beauty of obsolete oil rigs. Aust. Sci. 36, 28-30.

Fowler, A. M., Macreadie, P. I., Jones, D. O. B., and Booth, D. J. (2014). A multi-criteria decision approach to decommissioning of offshore oil and gas infrastructure. Ocean Coast. Manag. 87, 20-29. doi: 10.1016/j.ocecoaman.2013. 10.019

Friedlander, A. M., Ballesteros, E., Fay, M., and Sala, E. (2014). Marine communities on oil platforms in Gabon, West Africa: high biodiversity oases in a low biodiversity environment. PLoS One 9:e0103709. doi: 10.1371/journal.pone. 0103709

Frumkes, D. R. (2002). The status of the California rigs-to-reefs Programme and the need to limit consumptive fishing activities. ICES J. Mar. Sci. 59, S272-S276. doi: $10.1006 / j m s c .2002 .1289$

Fujii, T., and Jamieson, A. J. (2016). Fine-scale monitoring of fish movements and multiple environmental parameters around a decommissioned offshore oil platform: a pilot study in the North Sea. Ocean Eng. 126, 481-487. doi: 10.1016/j.oceaneng.2016.09.003

Gass, S. E., and Roberts, J. M. (2006). The occurrence of the cold-water coral Lophelia pertusa (Scleractinia) on oil and gas platforms in the North Sea: colony growth, recruitment and environmental controls on distribution. Mar. Pollut. Bull. 52, 549-559. doi: 10.1016/j.marpolbul.2005.10.002

Graham, N. A. J., Bellwood, D. R., Cinner, J. E., Hughes, T. P., Norström, A. V., and Nyström, M. (2013). Managing resilience to reverse phase shifts in coral reefs. Front. Ecol. Environ. 11, 541-548. doi: 10.1890/120305

Graham, N. A. J., Jennings, S., MacNeil, M. A., Mouillot, D., and Wilson, S. K. (2015). Predicting climate-driven regime shifts versus rebound potential in coral reefs. Nature 518, 1-17. doi: 10.1038/nature14140

Graham, N. A. J., and Mcclanahan, T. R. (2013). The last call for marine wilderness? Bioscience 63, 397-402. doi: 10.1525/bio.2013.63.5.13

Guerin, A. J., Jensen, A. C., and Jones, D. (2007). "Artificial reef properties of North Sea oil and gas production platforms," in Proceedings of the Oceans '07 IEEE Aberdeen, Marine Challenges: Coastline to Deep Sea (Richardson, TX: IEEE), 785-800.

Hakam, A., and Thornton, W. (2000). "Case history?: decommissioning, reefing, and reuse of Gulf of Mexico platform complex," in Proceedings of the Annual Offshore Technology Conference, Houston, TX, 1-7.

Hamzah, B. A. (2003). International rules on decommissioning of offshore installations: some observations. Mar. Policy 27, 339-348. doi: 10.1016/S0308597X(03)00040-X

Hehre, E. J., and Meeuwig, J. J. (2015). Differential response of fish assemblages to coral reef-based seaweed farming. PLoS One 10:e0118838. doi: 10.1371/journal. pone. 0118838

Henrion, M., Bernstein, B., and Swamy, S. (2015). A multi-attribute decision analysis for decommissioning offshore oil and gas platforms. Integr. Environ. Assess. Manag. 11, 594-609. doi: 10.1002/ieam.1693

Hobbs, R. J., Arico, S., Aronson, J., Baron, J. S., Bridgewater, P., Cramer, V. A., et al. (2006). Novel ecosystems: theoretical and management aspects of the new ecological world order. Glob. Ecol. Biogeogr. 15, 1-7. doi: 10.1111/j.1466-822X. 2006.00212.x
Hobbs, R. J., Higgs, E. S., and Hall, C. M. (2013a). "Defining Novel Ecosystems," in Novel Ecosystems: Intervening in the New Ecological World Order, eds R. J. Hobbs, E. S. Higgs, and C. M. Hall, (Chichester: Wiley), 58-60. doi: $10.1002 / 9781118354186 . c h 6$

Hobbs, R. J., Higgs, E. S., and Hall, C. M. (2013b). "What do we know about, and what do we do about, novel ecosystems?," in Novel Ecosystems: Intervening in the New Ecological World Order, eds R. J. Hobbs, E. S. Higgs, and C. M. Hall, (Chichester: Wiley-Blackwell).

Hobbs, R. J., Higgs, E. S., and Hall, C. M. (2017). Expanding the portfolio: conserving nature's masterpieces in a changing world. Bioscience 67, 568-575. doi: 10.1093/biosci/bix043

Hobbs, R. J., Higgs, E. S., and Harris, J. A. (2014). Novel ecosystems: concept or inconvenient reality? A response to Murcia et al. Trends Ecol. Evol. 29, 645-646. doi: 10.1016/j.tree.2014.09.006

IHS Markit, (2016). Offshore Decommissioning Study Report. Available at: https://news.ihsmarkit.com/press-release/energy-power-media/decommissio ning-aging-offshore-oil-and-gas-facilities-increasing-si (accessed March 10, 2018).

Jørgensen, D. (2009). An oasis in a watery desert? Discourses on an industrial ecosystem in the Gulf of Mexico Rigs-to-Reefs program. Hist. Technol. 25, 343-364. doi: 10.1080/07341510903313030

Jørgensen, D. (2012). OSPAR' s exclusion of rigs-to-reefs in the North. Ocean Coast. Manag. 58, 57-61. doi: 10.1016/j.ocecoaman.2011.12.012

Kaiser, M. J. (2006). The Louisiana artificial reef program. Mar. Policy 30, 605-623. doi: 10.1016/j.marpol.2005.04.005

Kaiser, M. J., and Liu, M. (2014). Decommissioning cost estimation in the deepwater U. S. Gulf of Mexico - Fixed platforms and compliant towers. Mar. Struct. 37, 1-32. doi: 10.1016/j.marstruc.2014.02.004

Kaiser, M. J., and Pulsipher, A. G. (2003). The cost of explosive severance operations in the Gulf of Mexico. Ocean Coast. Manag. 46, 701-740. doi: 10.1016/S09645691(03)00042-45

Kaiser, M. J., and Pulsipher, A. G. (2005). Rigs-to-reef programs in the Gulf of Mexico. Ocean Dev. Int. Law 36, 119-134. doi: 10.1080/00908320590943990

Laister, S., and Jagerroos, S. (2018). "Different routes - same destination: planning processes for decommissioning in South East Asia," in Proceedings of the Society of Petroleum Engineers Symposium, (Kuala Lumpur: Society of Petroleum Engineers).

Laurance, W., and Watson, J. (2016). Changes in our global footprint. Aust. Sci. 37, 36-37.

Löfstedt, R. E., and Renn, O. (1997). The brent spar controversy: an example of risk communication gone wrong. Risk Anal. 17, 131-136. doi: 10.1111/j.1539-6924. 1997.tb00852.x

Love, M. S., Schroeder, D. M., Lenarz, W., MacCall, A., Bull, A. S., and Thorsteinson, L. (2006). Potential use of offshore marine structures in rebuilding an overfished rockfish species, bocaccio (Sebastes paucispinis). Fish. Bull. 104, 383-390.

Love, M. S., Shroeder, D. H., and Nishimoto, M. M. (2003). Ecological Role of Oil and Gas Production Platforms and Natural Outcrops on Fishes in Southern and Central California: A Synthesis of Information. Seattle, WA: U. S. Department of the Interior.

Macdonald, J. M. (1994). Student note: artificial reef debate: habitat enhancement or waste disposal? Ocean Dev. Int. Law 25, 87-118. doi: 10.1080/ 00908329409546027

Macreadie, P. I., Fowler, A. M., and Booth, D. J. (2011). Rigs-to-reefs: will the deep sea benefit from artificial habitat? Front. Ecol. Environ. 9, 455-461. doi: 10.1890/100112

Macreadie, P. I., Fowler, A. M., and Booth, D. J. (2012). Rigs-to-reefs policy: can science trump public sentiment? Front. Ecol. Environ. 10, 179-180. doi: $10.1890 / 12 . w b .013$

Mccauley, D. J., Pinsky, M. L., Palumbi, S. R., Estes, J. A., Joyce, F. H., and Warner, R. R. (2015). Marine defaunation: animal loss in the global ocean. Science 347:1255641. doi: 10.1126/science. 1255641

Mcclanahan, T. R., and Mangi, S. (2000). Spillover of exploitable fishes from a marine park and its effect on the adjacent fishery. Ecol. Appl. 10, 1792-1805. doi: 10.1890/1051-0761(2000)010[1792:soeffa] 2.0.co;2

McLean, D. L., Partridge, J. C., Bond, T., Birt, M. J., Bornt, K. R., and Langlois, T. J. (2017). Using industry ROV videos to assess fish associations 
with subsea pipelines. Cont. Shelf Res. 141, 76-97. doi: 10.1016/j.csr.2017. 05.006

McLean, D. L., Taylor, M. D., Partridge, J. C., Gibbons, B., Langlois, T. J., Malseed, B. E., et al. (2018). Fish and habitats on wellhead infrastructure on the north west shelf of Western Australia. Cont. Shelf Res. 164, 10-27. doi: 10.1016/j.csr. 2018.05.007

Mimmi, F., Ralston, S., Silva, M. M., and Silva, P. M. (2017). "Baseline for planning and cost estimation of brazilian decommissioning," in Proceedings of the Offshore Technology Conference, Houston, TX.

Murcia, C., Aronson, J., Kattan, G. H., Moreno-Mateos, D., Dixon, K., and Simberloff, D. (2014). A critique of the "novel ecosystem" concept. Trends Ecol. Evol. 29, 548-553. doi: 10.1016/j.tree.2014.07.006

NERA, (2016). Oil \& Gas Industry Competitiveness Assessment. White Plains, NY: NERA.

OGP Decommissioning Committee, (2012). Decommissioning of Offshore Concrete Gravity Based Structures (CGBS) in the OSPAR Maritime Area/Other Global Regions. (London: International Association of Oil \& Gas Producers).

Oil and Gas UK, (2017). Decommissioning Insight 2017. (London: The UK Oil and Gas Industry Association Limited, trading as Oil \& Gas UK).

Page, H. M., Dugan, J. E., Culver, C. S., and Hoesterey, J. C. (2006). Exotic invertebrate species on offshore oil platforms. Mar. Ecol. Prog. Ser. 325, 101-107. doi: 10.3354/meps325101

Pajuelo, J. G., González, J. A., Triay-Portella, R., Martín, J. A., Ruiz-Díaz, R., Lorenzo, J. M., et al. (2016). Introduction of non-native marine fish species to the Canary Islands waters through oil platforms as vectors. J. Mar. Syst. 163, 23-30. doi: 10.1016/j.jmarsys.2016.06.008

Parente, V., Ferreira, D., and Moutinho, E. (2006). Offshore decommissioning issues: deductibility and transferability. Energy Policy 34, 1992-2001. doi: 10. 1016/j.enpol.2005.02.008

Phillips, C. R., Salazar, M. H., Salazar, S. M., and Snyder, B. J. (2006). Contaminant exposures at the $4 \mathrm{H}$ shell mounds in the Santa Barbara Channel. Mar. Pollut. Bull. 52, 1668-1681. doi: 10.1016/j.marpolbul.2006.06.012

Pietri, D., McAfee, S., Mace, A., Knight, E., Rogers, L., and Chornesky, E. (2011). Using science to inform controversial issues: a case study from the California ocean science trust. Coast. Manag. 39, 296-316. doi: 10.1080/08920753.2011. 566118

Pradella, N., Fowler, A. M., Booth, D. J., and Macreadie, P. I. (2014). Fish assemblages associated with oil industry structures on the continental shelf of north-western Australia. J. Fish Biol. 84, 247-255. doi: 10.1111/jfb.12274

Quist, L., and Nygren, A. (2015). Contested claims over space and identity between fishers and the oil industry in Mexico. Geoforum 63, 44-54. doi: 10.1016/j. geoforum.2015.05.015

Reggio, V. C. J. (1987). Rigs-to-Reefs. Fisheries 12, 2-7. doi: 10.1577/1548-844617- 14

Rijnsdorp, A. D., Buys, A. M., Storbeck, F., and Visser, E. G. (1998). Microscale distribution of beam trawl effort in the southern North Sea between 1993 and 1996 in relation to the trawling frequency of the sea bed and the impact on benthic. ICES J. Mar. Sci. 55, 403-419. doi: 10.1006/jmsc.1997. 0326

Robinson, D. P., Jaidah, M. Y., Jabado, R. W., Lee-Brooks, K., Nour El-Din, N. M., Al Malki, A. A., et al. (2013). Whale sharks, rhincodon typus, aggregate around offshore platforms in qatari waters of the arabian gulf to feed on fish spawn. PLoS One 8:e58255. doi: 10.1371/journal.pone.0058255

Salcido, R. E. (2005). Enduring optimism: examining the rig-to-reef bargain. Ecol. Law Q. 32, 863-937. doi: 10.15779/Z38HZ7Q

Sammarco, P. W., Lirette, A., Tung, Y. F., Boland, G. S., Genazzio, M., and Sinclair, J. (2014). Coral communities on artificial reefs in the Gulf of Mexico: standing vs. toppled oil platforms. ICES J. Mar. Sci. 71, 417-426. doi: 10.1093/icesjms/ fst034
Sanchez-Cuervo, A. M., Aide, T. M., Clark, M. L., and Etter, A. (2012). Land cover change in colombia: surprising forest recovery trends between 2001 and 2010. PLoS One 7:043943. doi: 10.1371/journal.pone.0043943

Scarborough-Bull, A. (1989). "Some comparisons between communities beneath the petroleum platforms off California and in the Gulf of Mexico," in Petroleum structures as artificial reefs: A compendium. Fourth International Conference on Artificial Habitats for Fisheries, Rigs-to-Reefs Special Session, ed. V. C. J. Reggio, (Miami, FL: OCS Study MMS).

Schläppy, M.-L., and Hobbs, R. J. (2019). A triage framework for managing novel, hybrid, and designed marine ecosystems. Glob. Chang Biol. Rev. doi: 10.1111/ gcb. 14757

Schroeder, D. M., and Love, M. S. (2002). Recreational fishing and marine fish populations in california. Calif. Coop. Ocean Fish. Investig. 43, 182-190.

Schroeder, D. M., and Love, M. S. (2004). Ecological and political issues surrounding decommissioning of offshore oil facilities in the Southern California Bight. Ocean Coast. Manag. 47, 21-48. doi: 10.1016/j.ocecoaman. 2004.03.002

Shinn, E. A. (1974). "Oil Structures as Artifial Reefs," in Proceedings of an International Conference on Artificial Reefs, (Houston: Texas A\&M University), 91-96.

Sommer, B., Fowler, A. M., Macreadie, P. I., Palandro, D. A., Aziz, A. C., and Booth, D. J. (2019). Decommissioning of offshore oil and gas structures Environmental opportunities and challenges. Sci. Total Environ. 658, 973-981. doi: 10.1016/j.scitotenv.2018.12.193

Stanley, D. R., and Wilson, C. A. (1989). Utilization of offshore platforms by recreational fishermen and scuba divers off the Louisiana coast. Bull. Mar. Sci. $44,767-775$.

Techera, E. J., and Chandler, J. (2015). Offshore installations, decommissioning and artificial reefs: do current legal frameworks best serve the marine environment? Mar. Policy 59, 53-60. doi: 10.1016/j.marpol.2015.04.021

Thomson, R. E., Mihaly, S. F., Rabinovich, A. B., McDuff, R. E., Veirs, S. R., and Stahr, F. R. (2003). Constrained circulation at Endeavour ridge facilitates colonization by vent larvae. Nature 424, 545-549. doi: 10.1038/nature01814

Todd, V. L. G., Warley, J. C., and Todd, I. B. (2016). Meals on wheels? A decade of megafaunal visual and acoustic observations from offshore Oil \& Gas rigs and platforms in the North and Irish Seas. PLoS One 11:e0153320. doi: 10.1371/ journal.pone.0153320

Wassenberg, T. J., Dews, G., and Cook, S. D. (2002). The impact of fish trawls on megabenthos (sponges) on the north-west shelf of Australia. Fish. Res. 58, 141-151. doi: 10.1016/s0165-7836(01)00382-4

Yakob, L., and Mumby, P. J. (2013). "Infectious disease and the novel Caribbean coral reef," in Novel Ecosystems: Intervening in the New Ecological World Order, eds R. J. Hobbs, E. S. Higgs, and C. M. Hall, (Hoboken, NY: Wiley-Blackwell), $118-123$.

Zawawi, N. A. W. A., Liew, M. S., and Na, K. L. (2012). "Decommissioning of offshore platform: A sustainable framework," in Proceedings of the 2012 IEEE Colloquium on Humanities, Science and Engineering (CHUSER), Kota Kinabalu, 26-31. doi: 10.1109/CHUSER.2012.6504275

Conflict of Interest Statement: The authors declare that the research was conducted in the absence of any commercial or financial relationships that could be construed as a potential conflict of interest.

Copyright (c) 2019 van Elden, Meeuwig, Hobbs and Hemmi. This is an open-access article distributed under the terms of the Creative Commons Attribution License (CC BY). The use, distribution or reproduction in other forums is permitted, provided the original author(s) and the copyright owner(s) are credited and that the original publication in this journal is cited, in accordance with accepted academic practice. No use, distribution or reproduction is permitted which does not comply with these terms. 